\title{
Human Capital, Industrial Structure Upgrading and Economic Growth in China: A Literature Review
}

\author{
Bai Yang ${ }^{1}$ \\ ${ }^{1}$ School of Economics, Central University of Finance and Economics, Beijing, China \\ Correspondence: Bai Yang, School of Economics, Central University of Finance and Economics, Beijing, China. \\ E-mail: baiyang870113@gmail.com
}

Received: May 13, 2020

doi:10.5539/ijbm.v15n8p59
Accepted: June 15, 2020

Online Published: July 2, 2020

\begin{abstract}
The research on human capital, industrial structure upgrading and economic growth has always been one of the focus issues in academia. The existing literature is developed from different perspectives. First of all, the research on human capital mainly focuses on the research of human capital and economic growth, including the relationship between total human capital and economic growth, the relationship between human capital structure and economic growth, and the relationship between healthy human capital and economic growth. Secondly, the research on the upgrading of industrial structure includes the upgrading of industrial structure and economic growth, the influencing factors of the upgrading of industrial structure and so on. Among them, the influencing factors mainly include technological progress, market supply and demand, population, trade and government policies. Thirdly, the research on the impact of human capital on the upgrading of industrial structure mainly includes the matching of heterogeneous human capital and industrial structure, and the impact mechanism of human capital on industrial structure. This paper systematically reviews the development of literature on human capital, industrial structure upgrading and their relationship, and points out the problems existing in the literature, possible improvements in the future and several issues that may need attention in the future.
\end{abstract}

Keywords: human capital, economic growth, industrial upgrading, China

\section{Introduction}

The research on human capital, industrial structure upgrading and economic growth has always been one of the focus issues in academic circles, and there is a close relationship among them. Around human capital, industrial structure upgrading and economic growth, scholars have done a lot of research. This paper tries to systematically review the development of literature research on human capital, economic growth and industrial structure upgrading, summarize and prospect the shortcomings of current research, and some possible improvements in the future in this field.

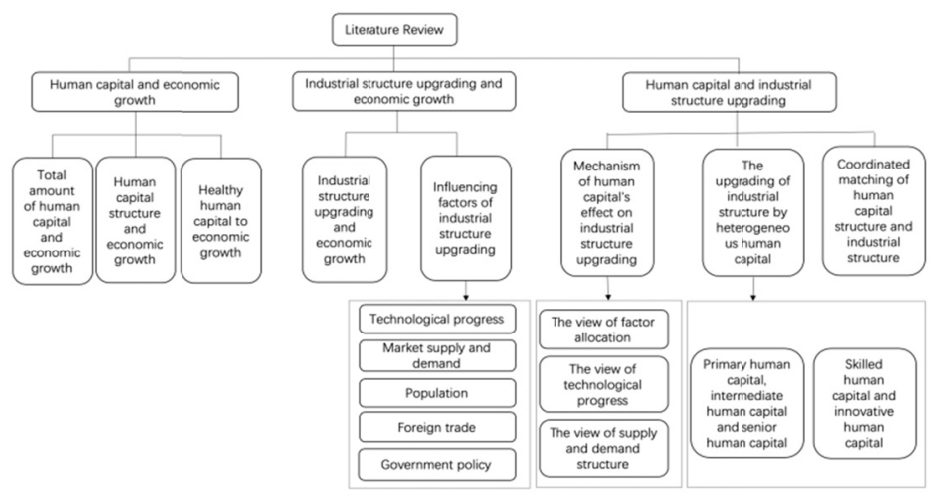

Figure 1. Literature review framework

The following specific arrangements are as follows: the second part introduces the methodology; the third part 
introduces the literature review of human capital and economic growth; the fourth part introduces the literature review of industrial structure upgrading and economic growth; the fifth part introduces the literature review of human capital and industrial structure upgrading; the sixth part is the conclusion.

\section{Methodology}

The author searched 109 papers from SSCI (Social Science Citation Index) and CSSCI (China Social Science Citation Index). Through the key words of "industrial upgrading", "human capital", "economic growth", "heterogeneity" and "matching", the specific paper list is obtained. Among them, SSCI papers are mainly from Elsevier, Springer, Wiley and other international authoritative academic publishers' websites, and CSSCI papers are mainly from CNKI (China National Knowledge Infrastructure).

\section{Human Capital and Economic Growth}

An important "fact" of economic growth is that many countries have experienced long-term and stable economic growth (Kaldor, 1963), especially some developed countries have entered a period of sustained and stable economic growth after entering the 1950s. In this context, the research on the relationship between human capital and economic growth is emerging.

One view is that the accumulation of human capital is an essential factor in the production of goods and services, which can promote economic growth. In other words, there is a positive relationship between the growth of human capital per capita and the output per capita. Solow (1956) found that the exogenous rate of technological change attached to the labor force offset the decrease in return on capital. But there are some defects in Solow's growth model, which ignores the externality of technological change and is difficult to define. Technological change can be understood as an unobservable residual "explanation" factor (i.e. "growth surplus") after other observable factors are considered. In order to make up for the shortcomings of Solow model, Schultz (1961) reinterprets the problem of "growth surplus" in the form of "human capital". Becker (1964) studied human capital investment, income and career choice from the micro level, and further improved the deficiencies of Schultz research. Since then, the concept of "human capital" has been widely concerned by economists, and has been introduced into the study of growth. Uzawa (1965) and Lucas (1988) further introduced the concept of "human capital" into a modern growth model. In this model (Lucas Uzawa theoretical framework), the production technology of workers is accumulated through endogenesis, that is, investment decision-making (school education, vocational training and work practice) aiming at wealth maximization reduces current consumption and improves future labor productivity and income. Under the steady-state equilibrium, the economic material capital and human capital grow at the same endogenous speed, and support the long-term economic growth. There is no distortion in human capital investment decision, and economic growth is efficient. Unfortunately, although the model supports human capital to promote sustained economic growth, it does not explain the specific details of the role of labor market and human capital investment in decision-making. Arrow (1962) put forward the "learning by doing" model. Using Cobb-Douglas production function, a production function with increasing returns to scale was derived, which endogenously generated the process of knowledge acquisition by workers. Arrow believed that workers acquire knowledge through learning, and constantly summarized experience, and then transformed knowledge into technology. Technological progress is the result of knowledge accumulation. Although Arrow didn't mention the concept of human capital, he has realized the importance of human capital accumulation. Later, Romer (1986), Stokey (1988) and young (1991) further deepened on the basis of Arrow (1962), and put forward the knowledge spillover model, believing that knowledge can promote economic growth.

In addition, Mankiw, Romer, and Weil (1992), Barro and Lee (1996, 2013) and Barro (1997, 2013) also draw a similar conclusion that human capital can promote economic growth. However, Barro's research only considers the "quantity" of human capital, that is, it mainly uses the average education level to measure human capital. In order to fill the gap in the research on the "quality" of human capital, Hanushek \& Woessmann (2012) used standard test scores to measure the cognitive ability at the national level, making the research more comprehensive. Another view is that the accumulation of human capital promotes economic growth because the educated and trained skilled workers are more likely to promote new technological innovation and accept new production technologies. Nelson \& Phelps (1966) believed that higher level of human capital improved economic growth through production technology progress and application of technology. Welch (1966) found evidence from the micro level to support this view, he found that educated workers are more likely to accept new technology; similarly, Foster \& Rosenzweig (1996) found that in India, educated farmers are more likely to adopt new seed technology.

It is worth noting that the growth trend among countries is not the same. Some countries rely on the 
accumulation of human capital (material capital) to rise rapidly and achieve high-speed growth, while others are in a low growth state. In order to explain this growth problem, Becker et al. (1990) and Azariadis et al. (1990) successively proposed models on multiple growth equilibrium problems, and they agreed that human capital would lead to more human capital production. The human capital sector (for example, the education sector) is an intensive user of skilled workers. With the increase of human capital stock, the return rate of human capital investment in a country may rise rather than fall. This is because the larger the stock of human capital, the cheaper it is to produce more human capital. In this way, different countries may lead to different development paths due to different initial endowments, thus forming a variety of stable states. There may be low output, a small amount of human capital investment and a high birth rate, as well as a high return, more investment, technology and growth, and a low birth rate.

Traditional economic theory affirms that the accumulation of human capital is one of the fundamental reasons for promoting economic growth. However, scholars, represented by Daron Acemoglu, Simon Johnson and James Robinson (AJR for short), who insist on the viewpoint of "system determines growth", believe that system is the fundamental reason for growth. Superior system can improve human capital accumulation and TFP (Total Factor Productivity), and finally achieve growth (Acemoglu, 2014). That is to say, AJR believes that institution is the root cause of human capital accumulation, and Acemoglu et al. $(2001,2005)$ studies on Africa and Europe provide detailed evidence to supporting his view. Among them, Acemoglu et al. (2001) is the most representative. They use the mortality rate of early European colonists in the colonies as the instrumental variable of the system to estimate the contribution of the system to growth. However, the evidence of AJR is questioned by Glaeser et al. (2004). They believe that AJR ignores the possibility that colonists will flow into more high-quality immigrants in the process of "inclusive" colonial rule, thus improving the level of human capital in the region. That is to say, the difference of human capital level leads to the difference of system, which is the root cause of the difference of growth. The accumulation of human capital is the fundamental driving force of growth. However, Acemoglu et al. (2014) found new evidence to try to overturn Glaeser et al. (2004). From this point of view, AJR and Glaeser are arguing about whether the cause of growth is institutional difference or human capital level difference. Although the debate about the reasons for growth is still unresolved, it is beneficial to promote the development of the theory in this field.

Focusing on the study of China's problems, the research on human capital and economic growth has also produced fruitful results. It can be seen from the literature development in recent years that the domestic scholars generally believe that the accumulation of human capital is an important factor to improve China's economic growth.

\subsection{Total Amount of Human Capital and Economic Growth}

Tang (2006) analyzed China's human capital stock through the Solow model and Lucas model introducing human capital. He found that since the reform and opening up, China's human capital stock has been increasing, which leads to the increase of per capita physical capital. He confirmed that the increase of marginal return of human capital has promoted the increase of per capita physical capital and capital output ratio. Dai \& Bie (2006) discussed the choice of FDI (Foreign Direct Investment) industry in developed countries and the economic growth of developing countries within the framework of an endogenous growth model of both developed and developing countries. They found that whether FDI can bring technological progress and economic growth to developing countries depends on the accumulation of human capital in developing countries. Wei et al. (2009) found that human capital significantly promoted economic growth, but human capital structure had a negative impact on economic growth. Zhang (2015) reevaluated the stock of human capital and material capital in China, and found that the contribution of human capital to China's economic growth is relatively low, which is reflected in that the economic growth is still mainly realized by labor-intensive industries and additional investment, and improving the contribution of human capital is the key to realize industrial transformation and upgrading and economic growth.

\subsection{Human Capital Structure and Economic Growth}

Based on Mankiw, Romer \& Weil (1992) (referred to as "MRW" model), Yu (2006) constructed an endogenous growth model including human capital to analyze the impact of human capital investment structure on economic growth. He thinks that the importance of human capital investment to economic growth is greater than that of material capital. Ou \& Liu (2010) analyzed the relationship between comprehensive advantages of human capital and economic growth from the perspective of heterogeneity and adaptability of human capital. They found that although the overall level of human capital in developing countries is relatively low, they can still form comparative advantages and promote economic growth under the condition of good coordination and matching 
between heterogeneous human capital and industrial structure, material capital investment and technology. Li et al. (2010) used the upgrading panel data to empirically find that senior human capital measured by the proportion of employees with higher secondary school experience contributes more to per capita output; primary human capital measured by the proportion of employees with lower education background contributes less to per capita output. Chen \& Ma (2011) reflected the heterogeneity of human capital by constructing the dispersion of human capital (the degree of deviation between individual and average), and analyzed the relationship between human capital and economic growth. He found that the dispersion of human capital in areas with high (low) human capital stock is driven by the proportion of high (low) education population; and on the premise of the increase of dispersion of human capital, the economic growth in areas with high (low) human capital stock is relatively slow. Zhang (2012) analyzed the slow technological progress of enterprises in China by establishing a model of technological progress investment and human capital investment. He believed that the complementary form between human capital and technological progress was determined by the "short side rule", while the lower education return in China led to the slow accumulation of human capital, which affected the speed of technological progress, making enterprises Technological progress is slow. Tao et al. (2012) found that the optimization of China's human capital structure has a significant role in promoting the comparative advantage of manufactured products, which is more conducive to improving the technical content of manufactured products. Based on the theory of system coupling, the interaction between human capital and economic growth was studied by Wei \& Zhou (2013). They found that the coupling degree between provincial human capital and economic growth is relatively low, and gradually decreasing from east to west. The eastern and northeast regions pay more attention to the innovation ability of human capital, and the central and western regions pay more attention to the imitation ability of new technology.

\subsection{Healthy Human Capital to Economic Growth}

On the research of healthy human capital on economic growth, Fogel (1994a, 1994b, 2002,2004), Barro (1996); Roberts (2006) and other researchers have discussed the impact of healthy human capital and economic growth. Their views can be described from the following aspects: firstly, food supply can alleviate famine, avoid malnutrition and other diseases caused by long-term hunger, and improve the overall health and utility level of human beings, but it may also lead to the aging of population. Secondly, the improvement of food supply and nutrition level can enhance human body and labor productivity, which is one of the main reasons for economic growth. Wang (2015), a domestic scholar, has a systematic summary of the research progress on the relationship between health and economic growth and economic development. He thinks that the existing literature explains the relationship between health and economic growth from three aspects: firstly, health influences production function through various direct or indirect ways; secondly, health affects individual utility level, and then affects material capital / human capital investment in the way of healthy consumption / investment; thirdly, economic growth / development influences food, nutrition consumption and so on level of health.

Foreign literature is in a relatively mature stage from the perspective of research, quantity and other aspects, while domestic research on such issues started late. Yang et al. (2006) combined human capital in the form of education capital and health capital in the form of Cobb-Douglas to build an endogenous growth model, believing that the stock and accumulation of human capital contribute to economic growth. Wang et al. (2008) found that there is a positive correlation between the growth rate of healthy human capital investment and economic growth, while whether the positive correlation between healthy human capital investment and economic growth depends on the size of the former's crowding out effect on material capital, and the transition of healthy investment can be detrimental to economic growth. Wang (2012) further explored the relationship between healthy human capital, material capital and consumption and the impact on economic growth through the expanded Ramsey model. He found that the healthy human capital of Vogel type from consumption and nutrition could not become the driving force of endogenous economic growth, and could not produce long-term economic growth mechanism by itself. And cross-border data are used to test that the health investment gap can significantly affect the output of countries (Wang, 2016).

\section{Industrial Structure Upgrading and Economic Growth}

With the development of economy, an important law of industrial structure change is "Kuznets fact". First discovered by Kuznets $(1957,1973)$, kongsamut et Al. (2001) summarized the law of industrial change as "Kuznets facts", that is, the general law of industrial structure change is that with the rising of per capita GDP, the share of output value of agricultural sector in GDP is on the decline, the share of industrial sector is relatively flat, and the share of service sector is on the rise.

According to Lin (2002), the optimal industrial structure and technological structure are determined by 
endogenous factor endowment structure. The key factor for developing countries to achieve economic convergence is whether the government follows the principle of comparative advantage of factor endowment to guide the development direction of industrial and technological selection. Cai Fang et al. (2009) analyzed the evolution process of China's regional leapfrogging industry, and believed that based on the differences of China's regional economic development, the industrial transfer in the form of "wild goose array" could be realized in China, that is, the industrial layout in the form of industrial upgrading and transfer in coastal areas and industrial undertaking in the western and central regions, and the development of labor-intensive industries in the central and western regions based on rich comparative advantages of labor force. Zhang \& Wang (2009) found that the contribution of industrial structure changes to economic growth lies in two aspects: the gap of factor allocation efficiency between industries and the direction of resource transfer between industries. The greater the efficiency of factor allocation among industries, the greater the contribution of industrial structure changes to economic growth.

Some scholars believe that China's economy has potential hidden dangers under the appearance of rapid growth. For example, Liu et al. (2014) believed that there was a serious imbalance behind the rapid growth of China's economy, and a U-shaped trend. Among them, the industrial structure has been in a state of light or moderate imbalance for a long time, and has further intensified into a state of severe imbalance after 2002. Li et al. (2016) found that the tertiary industry has a greater contribution to the economic growth of eastern provinces, the secondary industry has a greater contribution to the economic growth of central provinces, while the economic growth of western regions is more dependent on the primary industry.

The existing literature mainly focuses on the following factors affecting the upgrading of industrial structure.

\subsection{Technological Progress}

Technological progress is one of the important determinants of industrial structure transformation and upgrading. At present, literature research focuses on two aspects. Firstly, it is demonstrated that technological progress is an important determinant of industrial structure changes. Liu et al. (2005) found that there was an internal correlation between the development of technological science and the industrial structure change of the long wave phenomenon of economy. Zhang \& Wang (2009) believes that the higher the level of economic development, the stronger the dependence of economic growth on technological progress. To achieve economic growth, we should not only pay attention to capital deepening, but also emphasize the importance of technological progress and industrial structure upgrading. (Wu, 2005). Sun (2008) believes that enterprise innovation is conducive to the cultivation of new industries, gradually replacing the old industries, in order to achieve the purpose of industrial upgrading. But the premise of enterprise innovation is that the demand structure can be upgraded, and enterprise innovation needs enough demand space. Fu Hong et al. (2013) found that innovation has a positive role in promoting the upgrading of industrial structure. Tao \& Zhou (2016) thought that there was a non-linear characteristic between technological innovation and industrial structure upgrading. In addition, technology selection played a very important role in industrial structure upgrading. Huang \& Li (2009) built a model of the relationship between technology selection, industrial structure upgrading and economic growth. They found that the industrial structure upgrading should follow the principle of regional comparative advantage of factor endowment to select technology, and then guide the direction of industrial structure upgrading. Secondly, it explores the transmission mechanism of industrial structure changes caused by technological progress. Chen (2008) constructed an economic growth model with different technological growth rate of intermediate products, emphasizing the importance of technological progress and the impact of technological growth rate on the change of industrial structure. This model explains that the difference of technology growth rate among the middle sectors leads to the difference of product price, and finally leads to the change of economic structure. This general model can explain the direction of industrial structure change by comparing the middle sector with the three major industries, which is basically consistent with the conclusion of "Kuznets fact".

\subsection{Market Supply and Demand}

Some scholars think that consumption structure is the factor that determines the direction of industrial structure change. Ren (2002) believed that the resource structure determines the industrial structure in the natural economy, while the income level determines the demand structure in the market economy, and the demand structure determines the industrial structure. Therefore, he proposed that narrowing the income gap between regions would help to achieve the convergence of regional structural industries. Qiao \& Zhou (2004) emphasized that the upgrading of industrial structure is based on the upgrading of demand structure. They believe that there is an inevitable relationship between the change of residents' consumption and the change of industrial structure 
because the adjustment of market mechanism ensures that the structure of social output is basically the same as that of demand. With the upgrading of residents' income level and consumption structure, the industrial structure will also be upgraded. Under the condition of closed economy, the change of industrial structure mainly depends on consumption structure, while under the condition of open economy, the change of industrial structure is jointly determined by consumption structure and import and export structure, and the influence of import and export structure on the change of industrial structure depends on the scale of foreign trade. Li \& Gong (2012) have similar views, but they emphasized that the gap between the change speed of consumption structure and the change speed of industrial structure should not be too large. The change of consumption structure slightly faster than the change of industrial structure can effectively stimulate technological progress and output to achieve the purpose of promoting industrial upgrading. The change of consumption structure faster than the change of industrial structure may lead to excessive production pressure Distorted production process is not conducive to the change of industrial structure. According to Sun (2008), the change of demand structure is an evolutionary process that includes "quantity" and "quality", while "quality" demand is the driving force of enterprise innovation, so as to realize the upgrading of industrial structure. In the case of insufficient demand space, the innovation ability of enterprises will be limited, which is not conducive to the emergence of new industries and the replacement of old industries, thus hindering economic growth and industrial upgrading. Under the open conditions, it is also conducive to the economic convergence of later developing countries. Based on the input-output model, Shen (2011) linked the final demand structure with the tertiary industrial structure, and found that the final demand structure is the direct factor leading to the formation of industrial structure. Based on the method of Shen (2011), Jia (2015) analyzed the relationship between the final demand structure and industrial structure in Jiangsu Province, and reached a similar conclusion.

\subsection{Population Factor}

The impact of population factors on industrial transformation and upgrading mainly includes population quantity, population quality and population structure. Among them, population quantity and population quality can be roughly summarized as human capital, which is the key part of this paper, and will be listed and summarized separately later. The research of population structure on industrial transformation and upgrading focuses on population aging. There is a debate about the impact of population aging on the upgrading of industrial structure. Some scholars believe that the aging population is not conducive to the upgrading of industrial structure, mainly because the aging population causes China to gradually lose the comparative advantage of labor-intensive industries. At present, China's human capital stock is relatively low, and the two functions together constitute the resistance of industrial structure transformation and upgrading (Cai \&Wang, 2012). The scholars who hold the opposite view think that the aging population can promote the upgrading of industrial structure. Wang et al. (2015) believed that there are two sides to the impact of population aging on industrial upgrading. They promote the upgrading of industrial structure by increasing the demand of aging industry, prolonging life span, increasing the accumulation of human capital, accelerating the arrival of Lewis turning point, so as to narrow the wage gap between the two sectors, and "force" the adjustment of industrial structure. At the same time, due to the decline of labor productivity, the burden of social aging is increasing. It hinders the upgrading of industrial structure and finds that the aging population is helpful to the upgrading of industrial structure in China. Liu \& Peng (2016) obtained similar views by building spatial econometric models.

\subsection{Trade}

There is a causal relationship between foreign trade and industrial structure, which promotes each other. According to Huang (2010), foreign trade is oriented by industrial structure, while restricting or promoting the optimization and upgrading of industrial structure. Foreign trade can provide signals for industrial restructuring and solve the structural shortage (surplus) of domestic product market. The relationship between foreign trade and industrial structure is mutual promotion and mutual restriction. Li \& Jiang (2010) think that the structure of foreign trade has a high correlation with the industrial structure, and foreign trade has a leading effect on the industrial structure, especially in labor-intensive industries; foreign trade has a significant impact on the upgrading of the industrial structure in the long term, but the short-term shortage is not obvious, and the policy can guide the adjustment of the industrial structure by adjusting the trade structure, Guo et al. (2017) obtained similar views. However, Ma Ying et al. (2012) believed that although foreign trade promoted economic growth, it was not conducive to the development of labor-intensive industries. Cheng \& Chen (2018) examined the relationship between foreign trade structure and industrial structure from the perspective of export domestic value-added, and found that industrial structure and export domestic value-added are mutually causal, and improving export domestic value-added will help promote the optimization and upgrading of industrial structure. In addition, there is heterogeneity in the adjustment of regional industrial structure. For example, Zuo (2019) 
found that expanding the export of primary products is not conducive to the upgrading of industrial structure in the eastern region, but conducive to the rationalization of industrial structure in the central region; the export of industrial manufactured products is conducive to the upgrading of industrial structure in the eastern and central regions in China.

\subsection{Government Policy}

The ways that the government adopts policy measures to influence the upgrading of industrial structure include fiscal policy and monetary policy. From the point of view of the existing literature, both fiscal policy and monetary policy have promoted the upgrading of industrial structure to a certain extent, but they have their own limitations, and they are generally recommended to be used together in policy adoption.

\subsubsection{Fiscal Policy}

Zhou (2003) thinks that two theoretical and practical preconditions need to be solved for the government to successfully use fiscal policy to promote the optimization and upgrading of industrial structure: on the one hand, the implementation of fiscal policy content and means should be unified with the goal of establishing public financial system; on the other hand, the relevance between national debt investment and industrial structure adjustment should be fully utilized. In the specific empirical research, more detailed problems have been fully tested. Through a simple linear regression model, Guo (2004) found that government expenditure plays a key role in the optimization and upgrading of China's industrial structure. Guo \& Lai (2010) compared the panel data model and found that the effect of fiscal policy on industrial structure adjustment is significant, while the effect of monetary policy is not obvious. Song \& Wang (2013) found that the government subsidy policy can significantly accelerate the speed of industrial structure adjustment in the short term, but the long-term effect is not significant, because it does not conform to the market rules with the government subsidy policy. In addition, they found that the higher the dependence of government subsidies on external financing, capital intensity and nationalization of industries, the more significant the effect of structural change. Chu \& Jian (2014) analyzed the effect of fiscal policy on industrial structure adjustment from the perspective of aggregate and structure. The results show that: firstly, from the perspective of gross effect, tax policy promotes the adjustment of industrial structure, while fiscal policy hinders the upgrading of industrial structure; secondly, from the perspective of structural effect, education and science and technology expenditure promotes the upgrading of industrial structure, while government investment expenditure and administrative expenditure hinder the upgrading of industrial structure. Mao \& Liu (2014) found that the fiscal and tax policies have the characteristics of threshold conversion for the upgrading of industrial structure by building a multi factor panel smooth transition model (PSTR). Luo \& Luo (2016) found that reasonable macro tax burden scale $(8.74 \%-11.44 \%)$ can promote the rationalization and upgrading of industrial structure. The second industry tax and "expenditure adjustment effect" are conducive to the upgrading of industrial structure, while the third industry tax and labor tax are not conducive to the upgrading of industrial structure; the capital tax and population urbanization are conducive to the rationalization of industrial structure, and the industrial tax is not conducive to the rationalization of industrial structure.

\subsubsection{Monetary Policy}

Zhang (2014) believed that the expected mechanism of monetary policy would change the fluctuation path of industrial change due to the "Pigou effect", further leading to the uncertainty of industrial structure transformation and upgrading. Through the construction of cross industry DSGE model, it is found that the expectation mechanism based on monetary policy will adjust the direction of policy expectation, so as to adjust the industrial structure. In addition, different industries have different responses to monetary policy under the expected mechanism. The short-term effect of labor-intensive industrial transformation is larger, while the long-term effect of traditional industrial transformation is larger. Pang (2016) believes that monetary policy has asymmetric effect in the upgrading of industrial structure, and monetary policy has certain limitations, and encourages the use of fiscal policy and monetary policy. First of all, the response of the three industries to the impact of monetary policy from strong to weak is in the order of secondary industry primary industry and tertiary industry. That is to say, the industry has the largest response to the impact of monetary policy, and the service industry has the smallest response to the impact of monetary policy; secondly, the monetary policy has limitations on the adjustment of industrial structure, for example, the impact of monetary policy can't significantly increase the proportion of high tech manufacturing and modern service industry. 


\section{Human Capital and Upgrading of Industrial Structure}

\subsection{Mechanism of Human Capital's Effect on Industrial Structure Upgrading}

After the arrival of Lewis turning point and the gradual disappearance of demographic dividend advantage, China's economic growth brought by the labor input model gradually fell into a bottleneck. Change the growth mode, and the upgrading of industrial structure constantly increases the demand for labor skills (Cai, 2012). In other words, the accumulation of human capital plays an important supporting role in the upgrading of China's industrial structure. Therefore, understanding the transmission path of human capital driven industrial structure transformation and upgrading literature is helpful to clarify its internal logic and mechanism of action. The existing literature views on this part are mainly reflected in the following aspects:

\subsubsection{The view of Factor Allocation}

The transformation and upgrading of human capital to industrial structure is mainly reflected in the optimal allocation of factor resources. As a factor of production, human capital not only has the general function of the factor of production, but also has the function of allocating other factors. Human capital, as an element of economic activities, has externality, which can effectively reduce the cost of enterprises and improve the efficiency of R\&D. The characteristics of externality are also the core of national comparative advantage (Dai, 2006). The essence of industrial structure adjustment, transformation and upgrading can be understood as the change of the proportion of many factors of production distribution based on human capital, or the process of factor resource redistribution. The role of human capital is mainly reflected in the replacement effect and agglomeration effect on resources (Gao, 2006). Some scholars also believe that, human capital expands the labor productivity gap between industries through production effect, and it improves the flow speed of production factors among departments through allocation effect. The two effects determine the direction and speed of industrial structure transformation and upgrading (Niu et al., 2013). The increase in the level of human capital accumulation will attract the agglomeration of other factors of production or resources, reduce the cost of production, and realize the increasing returns to scale. A representative example is the relationship between human capital and industrial agglomeration. The stock of human capital is an important factor affecting industrial agglomeration, especially for some high-tech industries (Peng, 2007; Liu, 2008). At the same time, industrial agglomeration will also promote the level of human capital in the agglomeration area (Wang, 2019), and even lead to the phenomenon of human capital agglomeration. The relationship between them is not a one-way causal relationship, but a mutual promoting "symbiotic effect" and "multiplier effect" (Sun, 2008). However, Wang (2019) found that the effect of industrial agglomeration on human capital accumulation has obvious regional heterogeneity, only in the eastern coastal areas of China, but not in the inland areas. In addition, the agglomeration of human capital also has a certain impact on the upgrading of industrial structure. Sun (2017) thought that there was a " $\mathrm{U}$ " relationship between human capital accumulation and industrial structure upgrading, and there was a threshold effect of economic development level. He found that human capital concentration would promote industrial structure optimization only when it crossed the threshold. In addition, Ji \& Lai (2018) defined the "precipitation coefficient of human capital" and measured and inspected the allocation of human capital in China's industries. They found that human capital tends to precipitate among industries. The greater the degree of administrative monopoly (the smaller), the industry's human capital density is, and the lower the efficiency of inter sector human capital allocation is, which is not conducive to the improvement of innovation performance Rise.

\subsubsection{The View of Technological Progress}

Technological progress is the internal power of industrial upgrading, and technological progress is the inevitable result of human capital accumulation to a certain stage. The accumulation of human capital is helpful to the $R \& D$ and innovation ability of enterprises. Generally speaking, there are two ways to improve the level of human capital in a country: firstly, to improve the level of human capital through immigration. Taking Britain as an example, the rise of Britain is closely related to the entry of immigrants and foreign businessmen. Britain developed from an island country in the middle Ages to the world's largest industrial country in the 18th century. During this period, a large number of immigrants significantly improved the level of human capital in the UK in a short period, and the entry of foreign businessmen brought huge capital. The joint effect of the two factors is the key factor for the rapid industrialization of Britain (Liu, 2010). Similarly, the development of the United States is closely related to the absorption of excellent talents in the world, providing human capital support for the realization of technological progress. Secondly, improve the level of human capital by improving the level of education, training and health of domestic residents. Individuals with innovative spirit usually have higher intelligence and abstract thinking ability (Root-Bernstein, 1989), and through professional training in specific 
fields, after mastering professional technology and having sufficient working experience, creative employees are often the main source of enterprise new ideas (Snell \& Dean, 1992), the possibility of its innovation ability being transformed into new technology will increase. In general, there is a positive correlation between the cultivation of innovation ability and the level of individual education, that is to say, individuals with higher education usually have higher innovation spirit (Koellinger, 2007). Education level is the main way of human capital accumulation, and the improvement of human capital level is conducive to the realization of technical professionalism and diversity (Hayek, 1945). The higher the level of human capital of managers (e.g., legal representatives, managers) and employees, the more likely the enterprise is to set up independent R\&D institutions (Wu, 2009). The industry level is more conducive to industrial transformation and upgrading. However, the low return of human capital and the lack of independent innovation are the main factors restricting the transformation and upgrading of industrial structure (Zeng, 2009). Although the absolute quantity of labor force is large, its relative quality is low, resulting in a low level of industrial structure, slow upgrading, and falling into the "low technology" balance (Zhang, 2010).

\subsubsection{The View of Supply and Demand Structure}

Change the consumption structure and promote the upgrading of industrial structure. As the carrier of human capital accumulation, labor plays an important role in both consumption and production. Firstly, when the labor force is in the role of producer (supply side), it is reflected in promoting technological progress and innovation through the accumulation of human capital, so as to realize the transformation and upgrading of industrial structure. Secondly, when the labor force is in the role of consumer (demand side), the accumulation of human capital, due to the nature of high return on investment, leads to the improvement of labor income, changes of consumption structure and quality Quantity, then from the product level to promote the change of supply structure and quality, leading to the change of industrial structure. For example, from the perspective of supply, Jin (2010) believes that the effective supply of human capital helps to accelerate the industrial transformation and upgrading. While in China, there are too many low-level human capital and less high-level human capital, so the supply of human capital cannot adapt to the change of industrial structure. From the perspective of demand, Gao \& Tao (2006) think that the large demand for human capital indicates that the industry is in the growth stage, while the demand for human capital quality indicates that the industry is in the transformation and upgrading stage.

\subsection{The Upgrading of Industrial Structure by Heterogeneous Human Capital}

The existing literature roughly distinguishes the impact of human capital heterogeneity on industrial structure upgrading from the following two perspectives.

\subsubsection{Primary Human Capital, Intermediate Human Capital and Senior Human Capital}

It is mainly based on the level of education. Li et al. (2010) found that the contribution to per capita output is from high-level human capital (the proportion of people with college degree or above in employment), middle-level human capital (the proportion of people with middle school degree in employment) and primary human capital (the proportion of illiterate and primary school degree in employment). He Julian, Li \& Zhao (2013) studied the impact of higher education human capital on the optimization and upgrading of industrial structure, and found that it has a significant role in promoting industrial updating. Liu et al. (2018) believe that the characteristics of the upgrading of human capital structure are gradual evolution from primary human capital to senior human capital, and the upgrading of human capital structure has a significant role in promoting the upgrading of technology structure and industrial structure. Moreover, their research can better explain the reasons for the differences in the development of the eastern and western regions.

\subsubsection{Skilled Human Capital and Innovative Human Capital}

Firstly, skilled human capital. The realization of sustained economic growth requires the adjustment of industrial structure. Industrial structure adjustment (upgrading) means that the demand for different types of human capital changes, especially the corresponding adjustment and matching of skilled human capital and industrial structure (Wang, 2011). Secondly, innovative human capital. Innovative human capital can be further divided into technological innovation human capital and management innovation human capital. Technological innovation human capital can be regarded as scientific researchers (for example, scientists, engineers, etc.) in the process of technological development, which is the source of technological progress and the guarantee for the industry to maintain sustainable competitiveness (Zhu \& Li, 2007). According to the law of industrial change, it generally evolves along the path from labor-intensive industry to capital intensive industry and then to technology intensive industry, especially the demand of technology intensive industry for technological innovation human capital is large, but the contribution of innovation human capital to the economic growth of high-tech industry is 
low as a whole, and the supply of human capital still has the problem of "quality" (Huo, 2010). Only technological innovation can't directly affect the upgrading of industrial structure so as to achieve economic growth. It needs to be supplemented by advanced and reasonable institutional arrangements, that is, institutional innovation. System innovation includes property right system innovation and management system innovation. The main body of institutional innovation is usually entrepreneurs with vision. Entrepreneur human capital plays an important role in the innovation of single enterprise and industrial cluster (Lin, 2009). On the one hand, it is reflected in system innovation, such as the design of incentive system and the diversification of enterprise property right structure; on the other hand, it is reflected in the integration and distribution of other resources (including other types of human capital) in the process of operation.

\subsection{Coordinated Matching of Human Capital Structure and Industrial Structure}

At present, China's human capital level is still at a relatively low level in terms of total amount, which is characterized by more low-level human capital and unbalanced distribution of regional human capital, which also affects the direction and speed of industrial structure adjustment (Jin, 2010). The level of human capital not only determines the optimal allocation ability of labor among industries, but also determines the type of technological progress (Jin, 2011). In particular, the upgrading of industrial structure is constrained by the human capital structure in the process of evolution from labor-intensive to technology intensive (Tang, 2014).

According to the research on the relationship between the distribution structure of human capital and industrial structure, the existing literature basically supports the view that the distribution structure of human capital is not conducive to the optimization and upgrading of industrial structure. Specifically, Zhang \& Li (2011) found that the coordination and adaptation level of talent structure and industrial structure in each province was not high based on the coupling system of talent structure and regional industrial structure constructed by synergetics theory. Zhang (2014) measured the coupling degree and correlation degree between human capital stock and industrial structure by using the grey correlation analysis method. They found that although there was a strong interaction between human capital and industrial structure evolution, the coupling degree was not particularly ideal, which led to low efficiency of factor allocation. Zhang \& Jiang (2016) found that the level of human capital can promote the rationalization and advancement of industrial structure by building a spatial panel data model, but the current distribution structure of human capital is not conducive to the rationalization and advancement of industrial structure. Lin et al. (2017) found that human capital stock and structure have spatial spillover effects on rationalization and upgrading of industrial structure respectively.

\section{Conclusion}

By sorting out the development context of domestic and foreign scholars' literature on human capital, industrial structure upgrading and economic growth, we can get the three conclusions: Firstly, human capital can significantly promote economic growth is widely recognized in the literature. Secondly, there is a close relationship between the upgrading of industrial structure and economic growth. Thirdly, there are different views on explaining the mechanism of human capital's effect on the upgrading of industrial structure. It can be roughly divided into factor allocation, technology progress and supply-demand structure. After distinguishing the heterogeneity of human capital, it is more helpful to discuss the internal mechanism of the above problems.

It is found that there is still room for further research in the following aspects.

On the one hand, there are abundant literatures and most of them only analyze from a certain perspective, without forming a systematic analysis framework to explain the internal mechanism of human capital to industrial upgrading. The existing literature studies the impact of human capital on industrial upgrading. The internal factors are mainly concentrated in three aspects: technological progress, consumption demand and structural change, factor supply and structural change; the external factors are concentrated in two aspects: foreign trade and industrial policy. The disadvantage is that the literature only emphasizes one or several of the influencing factors, and does not explain the analysis framework of the internal mechanism of the relationship between the two. It is of innovative significance to form a general analysis framework to explain the impact mechanism of human capital on industrial upgrading by integrating the existing literature.

On the other hand, the research on the coordination between human capital structure and industrial structure needs further study. The analysis of the relationship between human capital structure and industrial structure, most of the methods are grey correlation analysis, which is more suitable for the analysis of the coupling correlation between the two systems. However, the specific use of coupling analysis only divides the industrial structure into the first, second and third industry level, and does not go further into the coupling matching level of specific industries. This is also one of the key research directions in the future. 


\section{References}

Acemoglu, D., Francisco, G., \& James, A. R. (2014). Institutions, Human Capital and Development. Working Paper, No. 19933, National Bureau of Economic Research. https://doi.org/10.2139/ssrn.2392106

Acemoglu, D., Simon, J., \& James, A. R. (2001). The Colonial Origins of Comparative Development: An Empirical Investigation. American Economic Review, 91(5), 1369-1401.

Acemoglu, D., Simon, J., \& James, A. R. (2005). The Rise of Europe: Atlantic Trade, Institutional Change, and Economic Growth. American Economic Review, 95(3), 546-579. https://doi.org/10.2139/ssrn.355880

Arrow, K. J. (1962). Economic Implications of learning by doing. Review of Economic Studies, 29(80), 155-173. https://doi.org/10.1007/978-1-349-15430-2_11

Azariadis, C., \& Drazen, A. (1990). Threshold externalities in economic development. Quarterly Journal of Economics, 105, 501-526. https://doi.org/10.2307/2937797

Barro, R. J. (1996). Health and Economic Growth. Paper Presented at the Senior Policy Seminar on Health, Human Capital and Economic Growth: Theory, Evidence and Policies. Pan American Health Organization and Inter-American Development Bank. Washington, DC.

Barro, R. J. (1997). Determinants of Economic Growth: A Cross-Country Empirical Study. Cambridge: MIT Press.

Barro, R. J. (2013). Education and Economic Growth. Annals of Economics and Finance, 14, 301-328.

Barro, R. J., \& Lee, J. W. (1996). International measures of schooling years and schooling quality. American Economic Review, 86(2), 218-223.

Barro, R. J., \& Lee, J. W. (2013). A New Data Set of Educational Attainment in the World: 1950-2010. Journal of Development Economics, 104, 184-198. https://doi.org/10.1016/j.jdeveco.2012.10.001

Becker, G. S. (1964). Human Capital: Theoretical Analysis with Special Reference to Education. New York: Columbia University Press for NBER.

Becker, R., Murphy, K. M., \& Tamura, R. (1990). Human capital, fertility, and economic growth. Journal of Political Economy, 98, S12-S37. https://www.jstor.org/stable/2937630

Cai, F., \& Wang, M. Y. (2012). On the Status Quo of China's Human Capital--How to Explore New Sources of Growth after Demographic Dividends Disappear. Frontiers, (6), 56-65. https://doi.org/10.16619/j.cnki.rmltxsqy.2012.04.003

Chen, T. B. (2008). Sectoral Difference in Growth Rate of Technology and Change in Economic Growth Rate with Hump-shape. Economic Research Journal, (11), 102-111.

Chen, Z. C., \& Ma, H. Q. (2011). The Relationship between Dispersion, Catch-up Effect of Human Capital and Economic Growth. The Journal of Quantitative \& Technical Economics, (6), 21-36. https://doi.org/10.13653/j.cnki.jqte.2011.06.004

Cheng, Y. P., \& Chen, H. Y. (2018). Relationship between China Industrial Structure and Foreign Trade Structure: An Empirical Study Based on Perspective of Export Domestic Added Value. Journal of Shandong University of Finance and Economics, (5), 17-26.

Dai, Q., \& Bie, C. X. (2006). FDI, Human Capital and Economic Growth. Economic Research Journal, (4), 15-27.

Dai, Q., \& Bie, C. X. (2006). Human capital, Dynamic Comparative Advantages and the Upgrading of Industrial Structure of Development Countries. The Journal of World Economy, (11), 70-84.

Fogel, R. W. (1994). Economic growth, population theory and physiology: The Bearing of Long-run Processes on the Making of Economic Policy. American Economic Review, 84(3), 369-395. http://www.jstor.org/stable/2118058

Fogel, R. W. (1994). The relevance of Malthus for the study of mortality today. NBER Working Paper, h5004.

Fogel, R. W. (2002). Nutrition, physiological capital, and economic growth. Paper presented at the "Senior Policy Seminar on Health, Human Capital and Economic Growth: Theory, Evidence and Policies. Pan American Health Organization and Inter-American Development Bank. Washington, DC.

Fogel, R. W. (2004). Health, Nutrition, and Economic Growth. Economic Development and Cultural Change, 52, 643-658. 
Foster, A. D., \& Rosenzweig, M. R. (1996). Technical change and human-capital returns and investments: evidence from the green revolution. American Economic Review, 86, 931-953. http://www.jstor.org/stable/2118312

Fu, H., Mao, Y. S., \& Song, L. S. (2013). Empirical Analysis on the Effect of Innovation on Advancement of Industrial Structure Process-Based on Panel Data of Provinces from 2000 to 2011. China Industrial Economics, (9), 56-68. https://doi.org/10.19581/j.cnki.ciejournal.2013.09.006

Gao, H. T., \& Tao, T. (2006). An Empirical Study on the Relationship between the Change of Industrial Structure and the Allocation of Human Resources in Western China. Search Magzine, (5), 32-34. https://doi.org/10.16059/j.cnki.cn43-1008/c.2006.05.010

Glaeser, E., Rafael, L. R., Florencio, L., \& Andrei, S. (2004). Do Institutions Cause Growth? Journal of Economic Growth, 9(3), 271-303. https://www.jstor.org/stable/40215873

Grossman, G., \& Helpman, E. (1991). Innovation and growth in the global economy. Cambridge, MA: MIT Press.

Guo, J. (2004). An Empirical Analysis of the Impact of Government Expenditure on Industrial Structure in China. Comparative Economic \& Social Systems, (3), 121-126.

Hanushek, E., \& Ludger, W. (2012). Do Better Schools Lead to More Growth? Cognitive Skills, Economic Outcomes and Causation. Journal of Economic Growth, 17(4), 267-321. https://doi.org/10.1007/s10887-012-9081-x

Hayek, F. (1945). The Use of Knowledge in Society. American Economic Review, 35(4), 519-532. https://doi.org/10.2307/1809376

He, J. L., Li, J., \& Zhao, D. (2013). The Empirical Research on Human Capital of Higher Education to Promote Industrial Structure Optimization and Upgrading. Education and Economy, (2), 48-55.

Huang, M. X., \& Li, J. J. (2009). Technology Choice, Upgrade of Industrial Structure and Economic Growth. Economic Research Journal, (7), 143-151.

Huang, Q. B., \& Fan, H. M. (2010). Foreign Trade, Economic Growth and Upgrading of Industrial Structure: an Empirical Test Based on China, India and Asian "Four Little Dragons". Journal of International Trade, (2), 38-44. https://doi.org/10.13510/j.cnki.jit.2010.02.002

Huo, W. W., \& Luo, J. L. (2010). An Empirical Study on the Contribution of Innovative Human Capital to the Economic Growth of China's High-tech Industry. Innovation, (3), 63-66.

Ji, W. W., \& Lai, D. S. (2018). Human Capital Allocation and China's Innovation Performance. Economic Perspectives, (11), 19-31.

Jia, X. F. (2015). A Quantitative Study on the Interaction Between the Final Demand Structure and Industrial Structure in Jiangsu Province. Jiangsu Social Sciences, (6), 260-267. https://doi.org/10.13858/j.cnki.cn32-1312/c.2015.06.037

Jin, W. D. (2010). The Effect of Dynamic Maching between Human Capital and Industrial Structure Transformation. Economic Review, (6), 137-142. https://doi.org/10.19361/j.er.2010.06.017

Jin, W. D. (2011). A Study on the Matching Relation between Industrial Structure Transforming and Human Capital in Shandong Province. Soft Science Research, (4), 60-63.

Koellinger, P. (2007). Why Are Some Entrepreneurs More Innovative Than Others? Erasmus Research Institute of Management, Report Series, ERS-2007-024-ORG.

Kongsamut, P. S. R., \& Xie, D. Y. (2001). Bayond Balanced Growth. Review of Ecnomic Studies, 68, 869-882. https://doi.org/10.1111/1467-937X.00193

Kuznets, S. (1973). Modern Economic Growth: Findings and Reflections. American Economic Review, 63, 829-846. https://www.jstor.org/stable/1914358

Li, X. B., Lin, X. B., \& Kong, D. Q. (2016). The Influence of Dynamic Industrial Structure on the Economic Growth in China. Economic Geography, (5), 100-106. https://doi.org/10.15957/j.cnki.jjdl.2016.05.014

Li, X. M., Yu, W. H., \& Huang, L. X. (2010). Human Capital Hierarchy Structure and Regional Economics Difference: Testing Based on the Panel Data of 28 Provinces and District in China. Journal of Chaohu College, (5), 30-35. 
Lin, C. Y., Kong, F. C., \& Meng, X. Y. (2017). Research on Spatial Effect of Human Capital on Industrial Transformation and Upgrading-Based on Dynamic Spatial Durbin Model. Review of Economy and Management, (6), 122-129. https://doi.org/10.13962/j.cnki.37-1486/f.2017.06.014

Lin, H. L. (2009). The role of Entrepreneur Human Capital in the Innovation Mechanism of Industrial Clusters: A Case Study of Zhejiang Province. Enterprise Economy, (7), 72-74.

Liu, J. H. (2010). Immigrants and Foreign Merchants: External Factors in the Rise of England. Historical Research, (1), 138-159.

Liu, J., Chen, J., \& Jiang, C. L. (2008). An Empirical Study on the Effect of Human Capital on Industrial Agglomeration. Statistics \& Decision, (19), 103-104. https://doi.org/10.13546/j.cnki.tjyjc.2008.19.017

Liu, Q. H., Fan, F., Ge, H. J., \& Xu, B. S. (2005). Study on Statistical Relativity between Development of Technological Sciences and Evolution of Industry Structure. Studies in Science of Science, (2), 160-168. https://doi.org/10.16192/j.cnki.1003-2053.2005.02.004

Liu, Y. F., \& Peng, D. D. (2016). Does Population Aging Block the Upgrade of Industrial Structure?-Spatial Econometric Research Based on China's Provincial Panel Data. Journal of Shanxi University of Finance and Economics, (3), 12-21. https://doi.org/10.13781/j.cnki.1007-9556.2016.03.002

Liu, Z. Y., Li, H. Z., Hu, Y. Y., \& Li, C. H. (2018). Human Capital Structure Upgrading and Economic Growth: A Reconsideration of Disparities among China's Eastern, Central and Western Regions. Economic Research Journal, (3), 50-63.

Lu, J., \& Zhou, H. M. (2013). Empirical Analysis of Coupling Relationship between Human Capital and Economic Growth in Chinese Province. The Journal of Quantitative \& Technical Economics, (9), 3-19. https://doi.org/10.13653/j.cnki.jqte.2013.09.013

Lucas, R. (1988). On the mechanics of economic development. Journal of Monetary Economics, 22, 3-42. https://doi.org/10.1016/0304-3932(88)90168-7

Luo, F. Z., \& Luo, N. S. (2016). How do Tax Burden Affect the Adjustment of Industrial Structure? -Based on the Level and Scale of Tax Burden. Industrial Economics Research, (1), 20-29. https://doi.org/10.13269/j.cnki.ier.2016.01.003

Lv, H. F., \& Wang, J. (2011). On the Relevance Between High-skilled Talents and Industrial Structure:Case Study in Zhejiang. Research in Higher Education of Engineering, (1), 67-72.

Ma, Y., Li, J., \& Yu, G. S. (2012). Trade Openness, Economic Growth and Adjustment of Labor-intensive Industrial Structure. Journal of International Trade, (9), 96-107. https://doi.org/10.13510/j.cnki.jit.2012.09.010

Maas, J., \& Van Lutsenburg, C. C. (1982). Distribution of Primary School Enrollments in Eastern Africa. World Bank Staff Working Papers, No.511. The World Bank, Washington DC.

Mankiw, G. N., Romer, D., \& Weil, D. N. (1992). A contribution to the empirics of economic growth. Quarterly Journal of Economics, 2, 407-437. http://dx.doi.org/10.2307/2118477

Mao, Y. S., Li, T., \& Wu, S. D. (2008). On the Transformation and Upgrading of China's Industry From the Perspective of Guangdong's Practice. Research on Economics and Management, (7), 16-21. https://doi.org/10.13502/j.cnki.issn1000-7636.2008.07.002

McDonald, S., \& Roberts, J. (2006). AIDS and Economic Growth: A Human Capital Approach. Journal of Development Economics, 80, 228-250. https://doi.org/10.1016/j.jdeveco.2005.01.004

Nelson, R., \& Phelps, E. (1966). Investment in humans, technological diffusion, and economic growth. American Economic Review, 56, 69-75. https://doi.org/10.1016/B978-0-12-554002-5.50015-7

Niu, Y. M., Cui, J. H., \& Yan, W. (2013). The Mechanism of Human Capital Influencing on Industry Structure Changing-Based on Empirical Analysis of Guangdong Area. On Economic Problems, (6), 10-16. https://doi.org/10.16011/j.cnki.jjwt.2013.06.006

Ou, X. Y., \& Liu, Z. Y. (2010). Human Capital's Comprehensive Advantages and Economic Growth in Large Developing Countries-Research Based on Heterogeneity and Adaptability. China Industrial Economics, (11), 26-35. https://doi.org/10.19581/j.cnki.ciejournal.2010.11.003

Peng, Z. W., \& Yan, C. C. (2007). Human Capital, R\&D Spillover and High-tech Industry Agglomeration. Science and Technology Management Research, (3), 147-148. 
Ren, T. Z. (2002). Demand Structure and Homogenization Trend of Regional Industrial Structure. Contemporary Economic Research, (3), 40-43.

Romer, P. (1986). Increasing returns and long-run growth. Journal of Political Economy, 94, 1002-1037. https://doi.org/10.1086/261420

Romer, P. (1990). Endogenous technological change. Journal of Political Economy, 98, S71-S102. http://dx.doi.org/10.1086/261725

Root-Bernstein, R. (1989). Who Discovers and Who Invents. Research Technology Management, 32(1), 43-51.

Schultz, T. W. (1961). Investment in human capital. American Economic Review, 1-17.

Snell, S., \& Dean, J. (1992). Integrated Manufacturing and Human Resource Management: A Human Capital Perspective. Academy of Management Journal, 35,467-504.

Solow, R. (1956). A contribution to the theory of economic growth. Quarterly Journal of Economics, 70, 65-94. https://doi.org/10.2307/1884513

Stokey, N. (1988). Learning by doing and the introduction of new goods. Journal of Political Economy, 96, 701-717. https://doi.org/10.1086/261559

Sun, H. B., Jiao, C. H., \& Lin, X. M. (2017). The Nonlinear Characteristics of the Impact of Human Capital Agglomeration on the Upgrading of Industrial Structure: An Empirical Study Based on PSTR Model. Economic Science, (2), 5-17. https://doi.org/10.19523/j.jjkx.2017.02.001

Sun, J. (2008). Demand Factor, Technology Innovation and the Industrial Structural Innovation. Nankai Economic Studies, (5), 58-71. HTTPS://DOI.ORG/10.14116/j.nkes.2008.05.004

Sun, J., \& You, W. (2008). Research on the Interactive Relationship Between Talent Agglomeration and $\begin{array}{llll}\text { Industrial Agglomeration. } & \text { Management } & \text { World, } & \text { 177-178. }\end{array}$ https://doi.org/10.19744/j.cnki.11-1235/f.2008.03.025

Tang, H. L. (2014). Research on Human Capital Structure, Technological Capital Allocation Structure and Industrial Transformation and Upgrading Ability. Statistics \& Decision, (2), 106-108. https://doi.org/10.13546/j.cnki.tjyjc.000085

Tang, X. J. (2006). Capital Deepening, Human Capital Accumulation and China's Sustained Economic growth. The Journal of World Economy, (8), 57-64.

Tao, C. Q., \& Zhou, X. (2016). A Study of Nonlinear Association and Spillover Effect of Technology Innovation and Industrial Structure Upgrading under Element Agglomeration. Contemporary Finance \& Economics, (1), 83-94. https://doi.org/10.13676/j.cnki.cn36-1030/f.2016.01.009

Tao, X. L., Yang, X. M., \& Hu, J. C. (2012). The Optimization of Human Capital Structure and the Dynamic Transformation of China's Comparative Advantages. Journal of Industrial Technological Economics, (8), $146-153$

Uzawa, H. (1965). Optimal technical change in an aggregative model of economic growth. International Economic Review, 6, 18-31. https://www.jstor.org/stable/2525621

Wang, C. H. (2019). Regional Heterogeneity, Industrial Agglomeration and Human Capital Accumulation: An Empirical Analysis Based on Regional Panel Data of China. Economic Survey, (1), 87-94. https://doi.org/10.15931/j.cnki.1006-1096.2019.01.005

Wang, D. H. (2012). Health Human Capital, Economic Growth and Poverty Trap. Economic Research Journal, (6), 143-155.

Wang, D. H., Cui, X. Y., \& Gong, L. T. (2015). The Role of Health in Economic Growth and Development: Based on the Perspective of Literature Research. Economic Perspectives, (8), 107-127.

Wang, D. H., Gong, L. T., \& Li, H. Y. (2008).Healthy Human Capital, Health Investment and Economic Growth. Management World, (3), 27-38. https://doi.org/10.19744/j.cnki.11-1235/f.2008.03.004

Wang, D. H., Huang, L., \& Li, H. Y. (2016). The Effect of Health Investment on Production Output: Based on a Cross-country (Region) Panel Data Analysis. Economic Research Journal, (8), 129-143.

Wang, W., Liu, Y. F., \& Peng, D. D. (2015). Research on Effects of Population Aging on Industrial Updating. China Industrial Economics, (11), 47-61. https://doi.org/10.19581/j.cnki.ciejournal.2015.11.004

Wang, Z. G., Gong, L. T., \& Chen, Y. Y. (2006). China's Regional Differences in Technical Efficiency and the 
Decomposition of Total Factor Productivity Growth (1978-2003). Social Sciences in China, (2), 55-56.

Wei, X. H., \& Li, S. P. (2009). Human capital, Human capital structure and regional economic growth: a quantile regression approach. Finance and Trade Research, 15-24. https://doi.org/10.19337/j.cnki.34-1093/f.2009.05.003

Welch, F. (1966). Education in production. Journal of Political Economy, 78, 35-59. https://doi.org/10.1086/259599

Wu, S. G. (2005). China's Capital Deepening, Technological Transformation and Industrial Structure Adjustment. Jiangsu Social Sciences, (5), 67-75. https://doi.org/10.13858/j.cnki.cn32-1312/c.2005.05.014

Wu, Y. B., \& Liu, X. H. (2009). Human Capital and R \&D Activity: Evidence from Chinese Private Enterprises. China Economic Quarterly, (4), 1567-1590. https://doi.org/10.13821/j.cnki.ceq.2009.04.010

Yang, J. F., Gong, L. T., \& Zhang, Q. H. (2006). Human Capital Formation and Its Influence on Economic Growth: An Endogenous Growth Model Including Education and Health Investment Test. Management World, (5), 10-34. https://doi.org/10.19744/j.cnki.11-1235/f.2006.05.002

Young, A. (1991). Learning by doing and dynamic effects of international trade. Quarterly Journal of Economics, 106, 369-406. https://doi.org/10.2307/2937942

Yu, C. L. (2006). Investment Structure of Human Capital and Its Economic Growth Effect: Endogenous Growth Theory and Empirical Research Based on Extended MRW Model. The Journal of Quantitative \& Technical Economics, (12), 117-125. HTTPS://DOI.ORG/10.13653/j.cnki.jqte.2006.12.013

Zeng, S. H., \& Zheng, J. H. (2009). Can Low Human Capital Returns Drive China' s Industrial Structure Upgrading. Finance \& Economics, (6), 71-78.

Zhang, G. W., \& Sun, Y. N. (2014). Empirical Research on Coupling Relationship Between Human Capital and Industrial Structure Evolution. Chinese Journal of Population Science, (6), 96-106.

Zhang, H. (2012). Human Capital Accumulation, Physical Investment and China's Slow Technology Progress. Journal of Nanjing Tech University (Social Science Edition), (3), 67-74.

Zhang, H., \& Wang, X. X. (2009). An empirical study on the contribution of industrial structure changes to economic growth in Beijing. Economic Science, (4), 53-61. https://doi.org/10.19523/j.jjkx.2009.04.005

Zhang, J. L. (2004). Research on the Current Situation and Countermeasures of the Coordination of Industrial structure and human capital structure in the western region. Gansu Social Science, (3), 170-174. https://doi.org/10.15891/j.cnki.cn62-1093/c.2004.03.048

Zhang, R. X. (2010). Human Capital, Technological Adoption and Industrial Upgrade. Finance \& Economics, (2), 66-74.

Zhang, W., Zheng, J., \& Huang, Y. L. (2014). An Analysis on Anticipated Shocks of Monetary Policy and Industrial Transmission: Based on a multi-sectoral DSGE Model. Journal of Financial Research, (6), 33-49.

Zhang, Y. (2015). Human Capital and China's Growth and Transformation. Economic Science, (1), 29-39. https://doi.org/10.19523/j.jjkx.2015.01.003

Zhang, Y. P., \& Li, M. S. (2011). Evaluation on Coordination and Matching Degree between Regional Talent Structure Optimization and Industrial Structure Upgrade in China. China Soft Science, (3), 177-192.

Zhang, Y., \& Jiang, X. M. (2016). The Impact of Human Capital on the Optimization and Upgrading of Industrial Structure: Based on Spatial Panel Data Model. Research on Financial and Economic Issues, (2), 106-113. https://doi.org/10.19654/j.cnki.cjwtyj.2016.02.015

Zhou, M. Q. (2003). On the Adjustment of Fiscal Policy to Support the Optimization of Industrial Structure. Nanjing Social Sciences, (11), 8-13. https://doi.org/10.15937/j.cnki.issn1001-8263.2003.11.002

Zhu, Q., \& Li, H. L. (2007). Research on the Effect of Technological Innovation Human Capital on Industrial Competitiveness: A Case Study of Guangdong Province. Contemporary Finance \& Economics, (7), 75-80.

Zon, A. H., \& Muysken, J. (2001). Health and Endogenous Growth. Journal of Health Economics, 20, 169-185. https://doi.org/10.1016/S0167-6296(00)00072-2

Zon, A. H., \& Muysken, J. (2003). Health as a Principal Determinant of Economic Growth. Working Paper, MERIT-Infonomics Research Memorandum.

Zuo, Y. H., \& Liu, B. B. (2019). The Research of the Impact of Export Trade Structure on RegionalIndustrial 
Adjustment and Upgrading. Journal of Hebei University of Economics and Business, (1), 81-89. https://doi.org/10.14178/j.cnki.issn1007-2101.2019.01.012

\section{Copyrights}

Copyright for this article is retained by the author(s), with first publication rights granted to the journal.

This is an open-access article distributed under the terms and conditions of the Creative Commons Attribution license (http://creativecommons.org/licenses/by/4.0/). 